\title{
Blasts 25 Percent or Less of Bone Marrow Nucleated Cells
}

National Cancer Institute

\section{Source}

National Cancer Institute. Blasts 25 Percent or Less of Bone Marrow Nucleated Cells. NCI Thesaurus. Code C156690.

A semi-quantitative microscopic finding indicating that 25 percent or less of the nucleated cells in a bone marrow sample are immature mononuclear cells. 